\title{
Influence of water and feeding frequencies on milk composition of dairy cows
}

\author{
Qurban Ali Memon ${ }^{1}$, Muhammad Haroon Baloch ${ }^{1}$, Muhammad \\ Naeem Rajput ${ }^{1}$, Muhammad Ghiasuddin Shah ${ }^{1}$, Asad Ali Khaskheli ${ }^{2 *}$, \\ Turab Ali Korejo ${ }^{1}$ and Mohsin Ali Solangi ${ }^{1}$ \\ 1. Department of Livestock Management, Sindh Agriculture University, Tandojam-Pakistan \\ 2. Department of Animal Nutrition, Sindh Agriculture University, Tandojam-Pakistan \\ *Corresponding author's email: khaskhelias@gmail.com \\ Citation \\ Qurban Ali Memon, Muhammad Haroon Baloch, Muhammad Naeem Rajput, Muhammad Ghiasuddin Shah, \\ Asad Ali Khaskheli, Turab Ali Korejo and Mohsin Ali Solangi. Influence of water and feeding frequencies on \\ milk composition of dairy cows. Pure and Applied Biology. Vol. 9, Issue 1, pp545-553.
} http://dx.doi.org/10.19045/bspab.2020.90060

\begin{tabular}{|c|c|c|c|}
\hline Received: 18/09/2019 & Revised: 01/12/2019 & Accepted: 04/12/2019 & Online First: 06/12/2019 \\
\hline
\end{tabular}

\section{Abstract}

This study was conducted at Danial dairy farm, Karachi. A total 15 Holstein friesian cows under $3^{\text {rd }}$ lactation were selected from 300 cows and were divided into 5 groups. Cows in group A (control) were offered ad-libitum feed and water, in group B; 2 time feed (Morning 6:00 AM and 6:00 PM) and ad-libitum water, in group C; 3 times feed (6:00 AM, 2:00 noon and 10:00 PM) and ad-libitum water, in group D; ad-libitum feed and 2 times water (6:00 AM and 6:00 PM), in group E; ad-libitum feed and 3 times water (6:00 AM, 2:00 noon and 10:00 PM). Results of present study indicated maximum protein $(3.62 \pm 0.12 \%)$ in group-B and minimum $(3.22 \pm 0.09 \%)$ in group-C. Lactose content was higher $(4.54 \pm 0.35 \%)$ in group-E and lower $(3.94 \pm 0.27 \%)$ in group-B. Maximum fat $(4.65 \pm 0.06 \%)$ was recorded in group-D and A, while minimum $(4.6 \pm 0.02 \%)$ was observed in group-A. Statistically significant difference occurred among group-A with $\mathrm{D}$ and $\mathrm{E}$ against fat percent. Solid-not-fat $(8.85 \pm 0.16 \%)$ was recorded higher in group-E and lower $(8.23 \pm 0.06 \%)$ in group-A. However, there was significant difference in solid not fat (\%) among group-A, B and E. Maximum total solids $(13.64 \pm 0.24 \%)$ were recorded in group-E and minimum $(13.39 \pm 0.14 \%)$ in group-B. Statistically significant difference among group-A, D and $\mathrm{E}$ was seen against total solids. Maximum ash $(0.66 \pm 0.03 \%)$ was recorded in group-A and minimum $(0.27 \pm 0.02 \%)$ in group-E, while among groupA, B and C significant variation occurred. Specific gravity $\left(1.03 \pm 1.45 \mathrm{~g} / \mathrm{cm}^{3}\right)$ was recorded maximum in group-A and minimum $\left(1.01 \pm 2.08 \mathrm{~g} / \mathrm{cm}^{3}\right)$ in group-C. Study concludes that the milk composition of Holstein friesian cows is considerably impaired by different dietary regimes. Protein found prominently improved in group-B, lactose and ash content were better in group-A, fat was higher in group-D, while solid-not-fat and total solids were better in group-E and $\mathrm{D}$, respectively.

Keywords: Cow; Feeding frequency; Lactation; Milk; Milk composition

\section{Introduction}

Water is an essential nutrient for sustaining the life and optimize the growth, lactation and reproduction of dairy cattle. However, due to continuous attention paid by dairy producers and nutritionists to other nutrients in the ration, often times the quality and provision of free drinking water does not receive the attention. The water requirement per unit of body mass of a high-producing dairy cow is greater than that of any other landbased mammal [1]. This is because of the high yield of milk secretion containing $87 \%$ water. Water is also required for digestion and metabolism of energy and 
nutrients, transport of nutrients and metabolites to and from tissues, excretion of waste products, maintenance of proper ions ratio, fluid and heat balance, fluid and cushioning environment for the developing fetus [2]. Total water content in the body of adult dairy cattle ranges between 56 and $81 \%$ of body weight depending upon stage of lactation cycle [3]. Loss of only about $20 \%$ of total body water is fatal. Meyer [4] reported that milk production increases with the increase of water intake. Little [5] reported that the reducing or decreasing watering had negative effect on milk production, where as free access to drinking water had a positive effect on milk yield. Aganga et al., [6] reported that water deprivation for 72 hours reduces milk production by $50 \%$ in lactating sheep and goats, but water deprivation for 72 hours causes an increase in the viscosity of milk as well as protein, fat and lactose content.

Dairy cows must consume large quantity of water for the better production of milk, while the amount that a cow drink depends largely upon the ambient temperature, the kind of feed consumed, milk yield and the temperature and cleanliness of the water. Voluntary water intake of cows for optimum milk production depends upon frequent access, without discomfort and moderate temperature. Most cattle normally consume 3 to 4 units of water for each unit of dry feed. Water requirements are directly related to dry matter intake i.e. increased consumption of dry matter will increase water consumption and vice versa. Milking cows require $4-5 \mathrm{~kg}$ of water for each $\mathrm{kg}$ of milk production [7].

Dairy cattle responses to various types of feeds and feeding arrangements. Dairy farmers can use knowledge of animal behavior to improve cow well-being and yield. For instance, feeding and watering systems must be placed, where young or inexperienced animals can find them [8]. Accessibility of feed may be more important than the actual amount of nutrients provided. Efforts must be made to reduce the competition for feed, water, minerals and shelter. Further, space; cow density and distribution of feed are also closely related factors. Feed intake and consequent milk yield are improved by provision of feed when cows need and want to eat. When one cow eats, another might be stimulated to do likewise, whether she is hungry or not. This behavior is an example of social facilitation when cows eat in groups, they eat more, compared to, when they are fed individually [9]. Moreover, cows kept in groups are likely to be less fearful, hence more contented, healthier, and more productive. The common practice of feeding and milking cows in groups thus has a sound psychological basis. The major criterion for improvement in production is to optimize the efficiency of utilization of the available fodder resource and not to attempt to maximize animal production [10]. There is little point in knowing the energy requirements of a cow for milk production, whose requirements are to be met from whatever crop residue is available. It is therefore very important to understand the requirements for supplements that will provide nutrients that will optimize the efficiency of utilization of that feed resource. The greatest scope for improving a country's milk production is through a strategy which targets improvement of production performance. Keeping in view these facts current study was planned, whereby objective of study was to find the effect of water and feeding frequencies on the milk composition of cows especially the Holstein friesian.

\section{Materials and methods}

Study was conducted at Danial Dairy farm, Karachi. Out of total 300 Holstein friesen $(\mathrm{n}=300) \quad$ cows, Fifteen $\quad(\mathrm{n}=15) \quad\left(3^{\text {rd }}\right.$ Lactation) were selected randomly and distributed into 5 groups. Cows in group A (control) were offered ad-libitum feed and water, in group B; 2 times feed (Morning 6:00 $\mathrm{AM}$ and 6:00 PM) and ad-libitum water, in group C; 3 times feed (6:00 AM, 
2:00 Noon and 10:00 PM) and ad-libitum water, in group D, ad-libitum feed and 2 times water (6:00 AM and 6:00 PM), in group E; ad-libitum feed and 3 times water (6:00 AM, 2:00 Noon and 10:00 PM). All Groups (A, B, C, D, and E) contained same composition of feed and water. Similar type of housing and bedding system was provided to the all experimental cows. Weekly milk samples were collected from all groups during the study period of 2 months and analyzed at Engro Laboratory, Kathor, Karachi for compositional parameters like protein, lactose, fat, solid-not-fat total solids, specific gravity and ash content.

\section{Protein}

Protein content was determined using method referred by AOAC, 2000. Sample (2ml) was digested using Micro-Kjeldhal digester in the presence of catalyst $(0.35 \mathrm{~g}$ Copper Sulphate and 7g Sodium Sulphate/ Potassium Sulphate), where Sulfuric acid $(30 \mathrm{ml})$ was used as an oxidizing agent. The digested sample was diluted with distilled water $(250 \mathrm{ml})$. Then diluted sample (5ml) was distilled with $40 \%$ sodium hydroxide solution using MicroKjeldhal distillation unit where steam was distilled over $2 \%$ boric acid $(5 \mathrm{ml})$ containing an indicator bromocresol green for $3 \mathrm{~min}$. The ammonia trapped in boric acid was determined by titrating with $0.1 \mathrm{~N}$ hydrochloric acid. The nitrogen percentage was calculated using the following formula:

Nitrogen $(\%)=\frac{1.4(\mathrm{~V} 1-\mathrm{V} 2) \times \text { normality of } \mathrm{HCl}}{\text { Weight of sample taken } x \text { volume of diluted sample }} \times 250$

Where,

$\mathrm{V} 1=$ Titrated value of milk sample

V2 = Titrated value of blank sample

Protein percentage was determined by using formula: protein percentage $=\mathrm{N} \% \mathrm{x}$ conversion factor $(\mathrm{CF})$.

\section{Lactose}

Lactose content was determined by difference method. The sum of total percent of fat, protein and ash contents was subtracted from that of total solids content.
Total fat content was determined by butyrometer (AOAC, 2000).

\section{Solids not fat}

The solids not fat was determined as per method described by AOAC (2000) using Digital Bench Refractometer. Before using instrument, it was properly cleaned and adjusted to zero at $20{ }^{\circ} \mathrm{C}$ using distilled water. An appropriate quantity of milk extracted was placed on the prism-plate of the refractometer with the help of a glass rod and folding back the cover. For each sample the instrument was calibrated by using distilled water. The reading appeared on the screen was directly recorded.

\section{Total solids}

For total solids, method recommended by (AOAC, 2000) was used. Before pouring the sample $(5 \mathrm{ml})$, the empty Aluminum dish was weighed. The dish was kept in hot air oven for 3 hours. The temperature of oven was adjusted at $101 \pm 1^{0} \mathrm{C}$ and then sample was transferred to desiccator. After $1 \mathrm{hr}$, the dish was weighed. The sample was dried and desiccated until a constant weight was achieved. The moisture/total solids was calculated by following the given formula.

Moisture $\%=\frac{\mathbf{W}_{2}-\mathbf{W}_{3}}{\mathbf{W}_{2}-\mathbf{W}_{1}} \times 100$

Total solids $\%=100-$ moisture $\%$

Where,

$\mathrm{W} 1$ = weight of empty dish

W2 = weight of dish + sample

$\mathrm{W} 3$ = weight of dish + weight of dried sample

Ash

Ash percentage was determined by Gravimetric method using muffle furnace as described by AOAC, (2000). The fresh milk sample $(5 \mathrm{ml})$ was transferred in preweighed crucible and transferred to muffle furnace $\left(550^{\circ} \mathrm{C}\right)$ for 5 hours. Ashed sample was transferred to desiccator having silica gel as desiccant. After 1 hour, the dish was weighed and the ash content was calculated applying the following formula:

Ash $(\%)=\frac{\text { Weight of ashed sample }}{\text { Weight of sample taken }} 100$ 


\section{Specific gravity}

The specific gravity was determined using pycnometer. The empty bottle was weighted, filled with distilled water and reweighed. It was then with sample of milk and weighed. The specific gravity of the milk was calculated, as Ishiwu and Oluka (2004), as follows:

Specific gravity $=\frac{\mathrm{WJ}}{\mathrm{Ww}}$

\section{Data analysis}

The collected data was tabulated and statistically analyzed by using statistical software Student Edition of Statistics (SXW) version 8.1 and presented as Mean \pm SE. Differences were considered significant at $(\mathrm{P}<0.05)$.

\section{Results and discussion}

Experimental trial was conducted on Holstein friesian cows in order observe the effect of different water and feeding frequencies on chemical milk components such as protein, lactose, fat, solid-not-fat total solids, specific gravity and ash content.

Regarding protein percent results are given in (Figure 1). Results showed maximum protein $(3.62 \pm 0.12)$ percent in milk of group $B$ and minimum $(3.22 \pm 0.09 \%)$ in the group C. However there was no significant variation in protein $(\%)$ between $\mathrm{A}, \mathrm{B}, \mathrm{C}, \mathrm{D}$ and $\mathrm{E}$ groups. These results are in line with reported findings of $[5,13]$. Lactose content was found maximum $(4.54 \pm 0.35 \%)$ in group $\mathrm{E}$ and minimum $(3.94 \pm 0.27 \%)$ in group B. However, statistically no significant variation was noted among all groups (Figure 2). Results regarding lactose content possessed strong connection with the study of $[1,13,14]$, who reported that the underfeeding of dairy cows reduces lactose percent.

Fat content in the different milk samples was analyzed and results are depicted in the (Figure 3). The data showed maximum fat content $(4.65 \pm 0.06 \%)$ in group D and $\mathrm{E}$, while minimum $(4.6 \pm 0.02 \%)$ in the group A. Statistically there was significant difference in group $\mathrm{A}$ with $\mathrm{D}$ and $\mathrm{E}$ against fat percent, while difference was non-significant among groups A, B and C, as well as between group $\mathrm{D}$ and $\mathrm{E}$, correspondingly. These findings relate with the results of $[6,13,14]$, who reported that the most of changes in milk composition especially the fat is due to dietary manipulation.

Solid not fat (\%) of milk samples of Holstein friesian milk is given in (Figure 4). The data showed that maximum solid not fat $(8.85 \pm 0.16 \%)$ was recorded in group $\mathrm{E}$ and minimum solid not fat $(8.23 \pm 0.06 \%)$ was recorded in group A. However, there was significant difference in solid not fat (\%) among groups A, B and $\mathrm{E}$, while non-significant difference between group $\mathrm{C}$ and $\mathrm{D}$. Concerning total solids in the milk samples of Holstein friesian findings are presented in the (Figure 5). It is shown in the table that the maximum total solids $(13.64 \pm 0.24 \%)$ was observed in the group $\mathrm{E}$ and minimum $(13.39 \pm 0.14 \%)$ was recorded in group B. However there was significant variation in total solids (\%) among group A, D and E, while non-significant variation between group $\mathrm{B}$ and $\mathrm{C}$. [11-18] also reported relevant kinds of findings when studied milk composition in relation with different dietary composition. Senn $[12,14,15,17$, 18] reported finding are also supportive to current study results.

Ash content of milk samples were analyzed and results are presented in the (Figure 6). Figure shows that the maximum ash $(0.66 \pm 0.03 \%)$ was seen in milk samples of group $\mathrm{A}$ and minimum $(0.27 \pm 0.02 \%)$ in group E. However there was significant difference in ash content among groups $\mathrm{A}, \mathrm{B}$ and $\mathrm{C}$, while nonsignificant difference between group $\mathrm{D}$ and E. Regarding specific gravity $\left(\mathrm{g} / \mathrm{cm}^{3}\right)$ of Holstein friesian milk results shown in (Figure 7) indicates maximum specific gravity $\left(1.03 \pm 1.45 \mathrm{~g} / \mathrm{cm}^{3}\right)$ in the milk samples of group $\mathrm{A}$ and minimum $\left(1.01 \pm 2.08 \mathrm{~g} / \mathrm{cm}^{3}\right)$ in group C. However 
there was non-significant difference in specific gravity $\left(\mathrm{g} / \mathrm{cm}^{3}\right)$ among groups A, $\mathrm{B}, \mathrm{C}, \mathrm{D}$ and $\mathrm{E}$. In comparison to current study [15-18] reported somewhat different results. Change in the results may be due different diet composition and environmental changes.

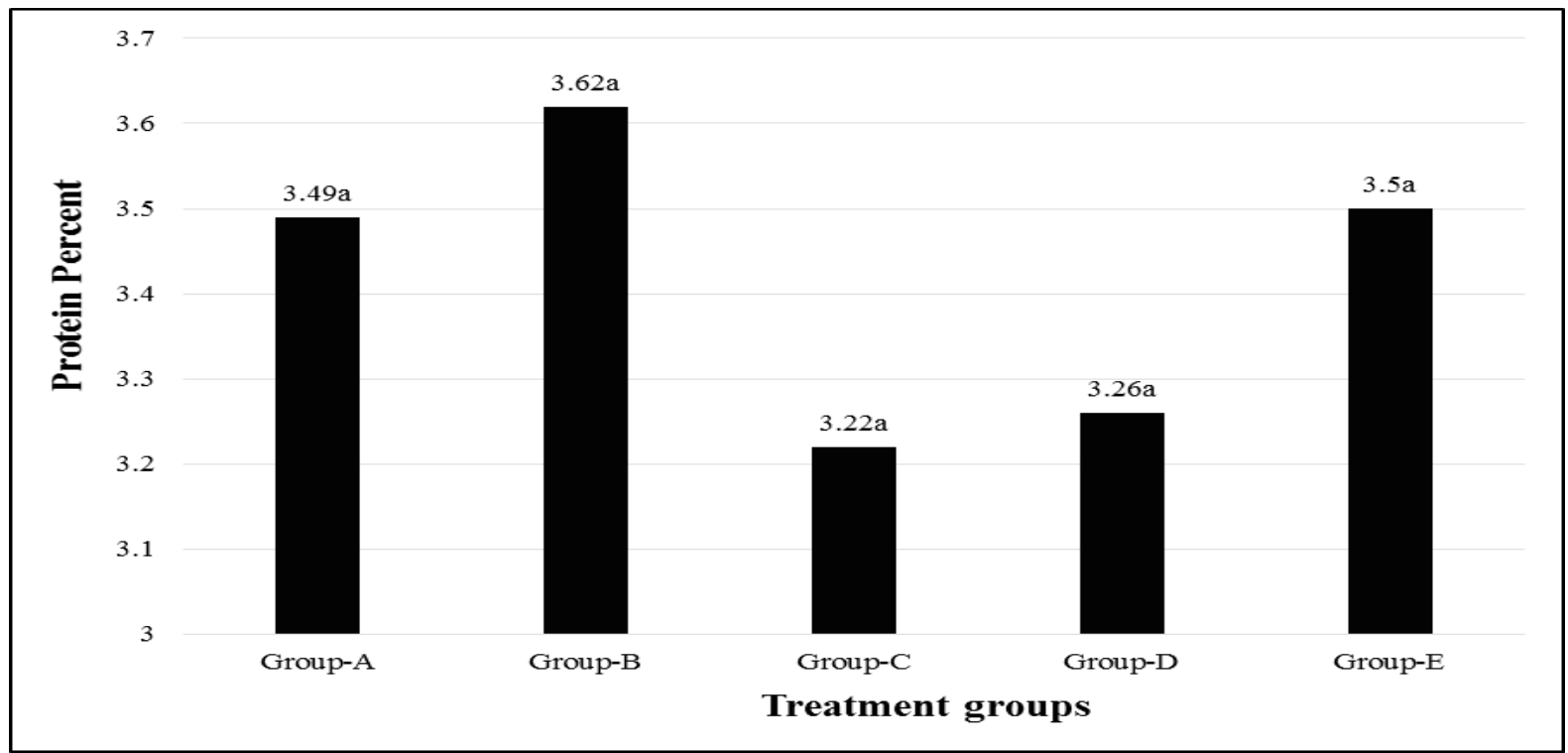

Group-A = Control (ad-libitum feed + water $)$

Group-B $=2$ times feed (Morning 6:00 AM and 6:00 PM) + ad-libitum water

Group-C $=3$ times feed (6:00 AM, 2:00 Noon and 10:00 PM) + ad-libitum water

Group-D = Ad-libitum feed for 24 hours +2 times water (6:00 AM and 6:00 PM)

Group-E = Ad-libitum feed for 24 hours +3 time water (6:00 AM, 2:00 PM and 10 PM)

Figure 1. Effect of different water and feeding frequencies on milk protein of Holstein friesian cows

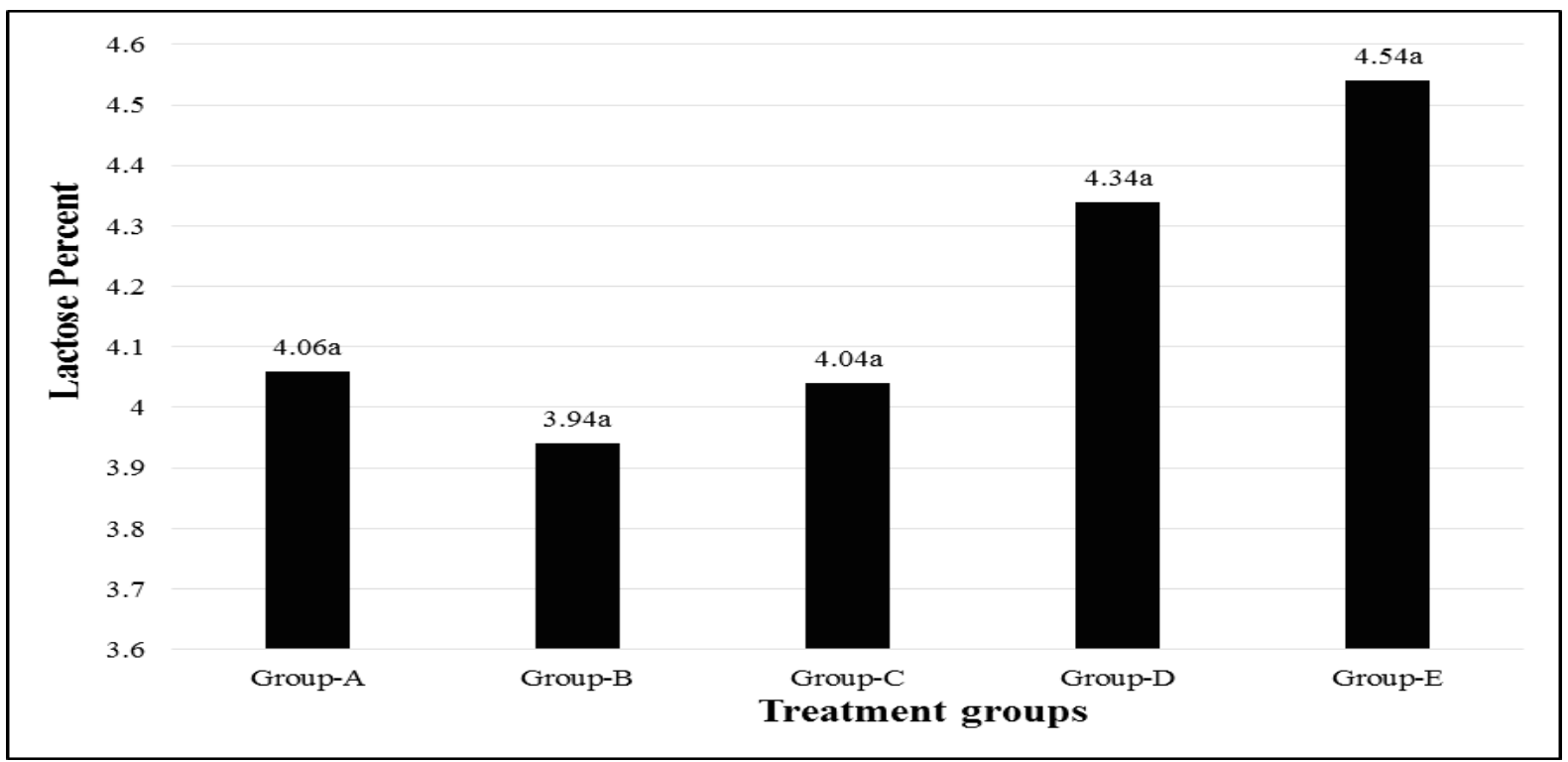

Group-A = Control (ad-libitum feed + water)

Group-B $=2$ times feed (Morning 6:00 AM and 6:00 PM) + ad-libitum water

Group-C $=3$ times feed (6:00 AM, 2:00 Noon and 10:00 PM) + ad-libitum water

Group-D $=$ Ad-libitum feed for 24 hours +2 times water (6:00 AM and 6:00 PM)

Group-E = Ad-libitum feed for 24 hours +3 time water (6:00 AM, 2:00 PM and 10 PM)

Figure 2. Effect of different water and feeding frequencies on milk lactose percent of Holstein friesian cows 


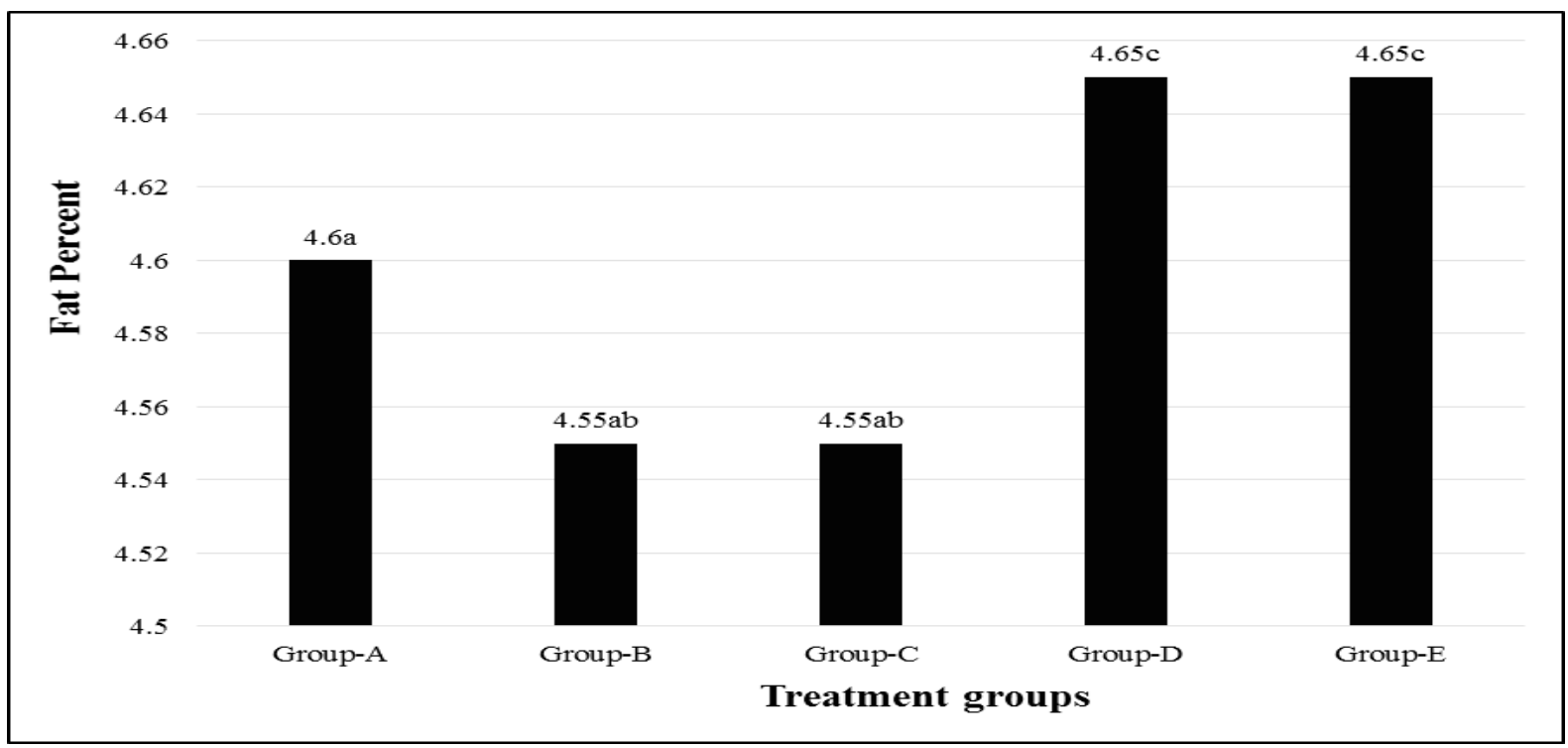

Group-A = Control (ad-libitum feed + water)

Group-B $=2$ times feed (Morning 6:00 AM and 6:00 PM) + ad-libitum water Group-C $=3$ times feed (6:00 AM, 2:00 Noon and 10:00 PM) + ad-libitum water Group-D $=$ Ad-libitum feed for 24 hours +2 times water (6:00 AM and 6:00 PM) Group-E = Ad-libitum feed for 24 hours +3 time water (6:00 AM, 2:00 PM and 10 PM)

Figure 3. Effect of different water and feeding frequencies on milk fat percent of Holstein friesian cows

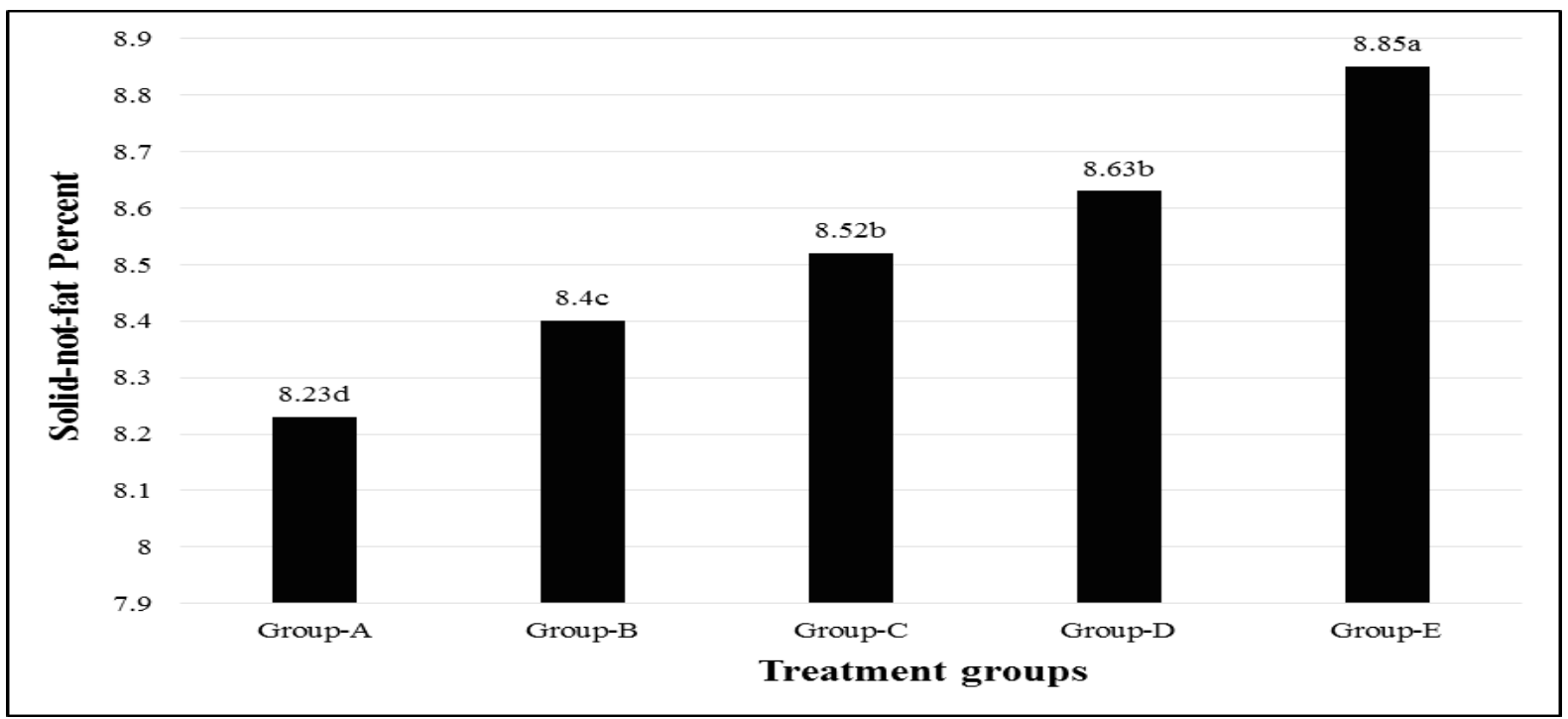

Group-A = Control (ad-libitum feed + water $)$

Group-B $=2$ times feed (Morning 6:00 AM and 6:00 PM) + ad-libitum water

Group-C $=3$ times feed (6:00 AM, 2:00 Noon and 10:00 PM) + ad-libitum water

Group-D $=$ Ad-libitum feed for 24 hours +2 times water (6:00 AM and 6:00 PM)

Group-E = Ad-libitum feed for 24 hours +3 time water (6:00 AM, 2:00 PM and 10 PM)

Figure 4. Effect of different water and feeding frequencies on solid-not-fat percent of Holstein friesian cows 


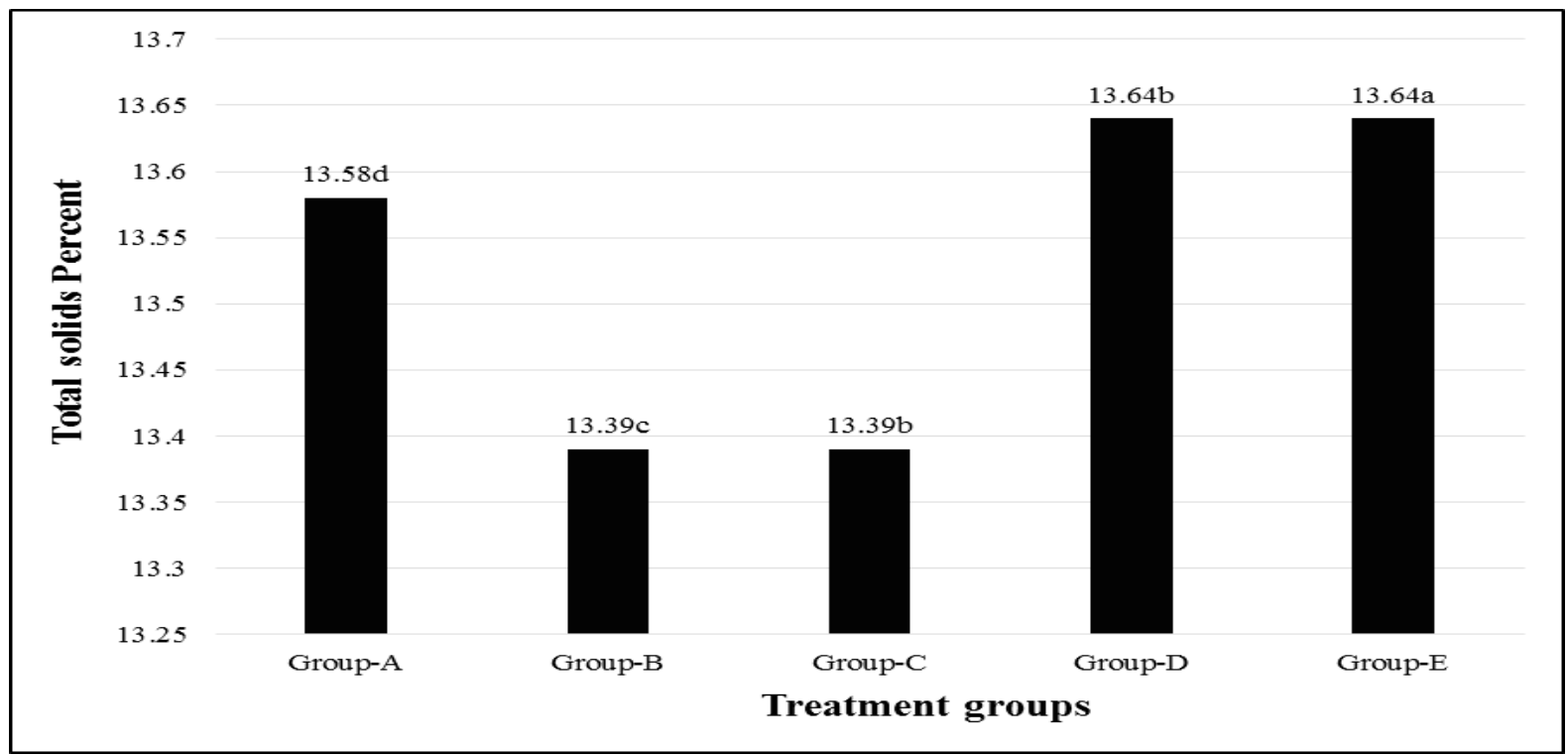

Group-A = Control (ad-libitum feed + water)

Group-B $=2$ times feed (Morning 6:00 AM and 6:00 PM) + ad-libitum water

Group-C $=3$ times feed (6:00 AM, 2:00 Noon and 10:00 PM) + ad-libitum water

Group-D = Ad-libitum feed for 24 hours +2 times water (6:00 AM and 6:00 PM)

Group-E = Ad-libitum feed for 24 hours +3 time water (6:00 AM, 2:00 PM and 10 PM)

Figure 5. Effect of different water and feeding frequencies on milk total solids of Holstein friesian cows

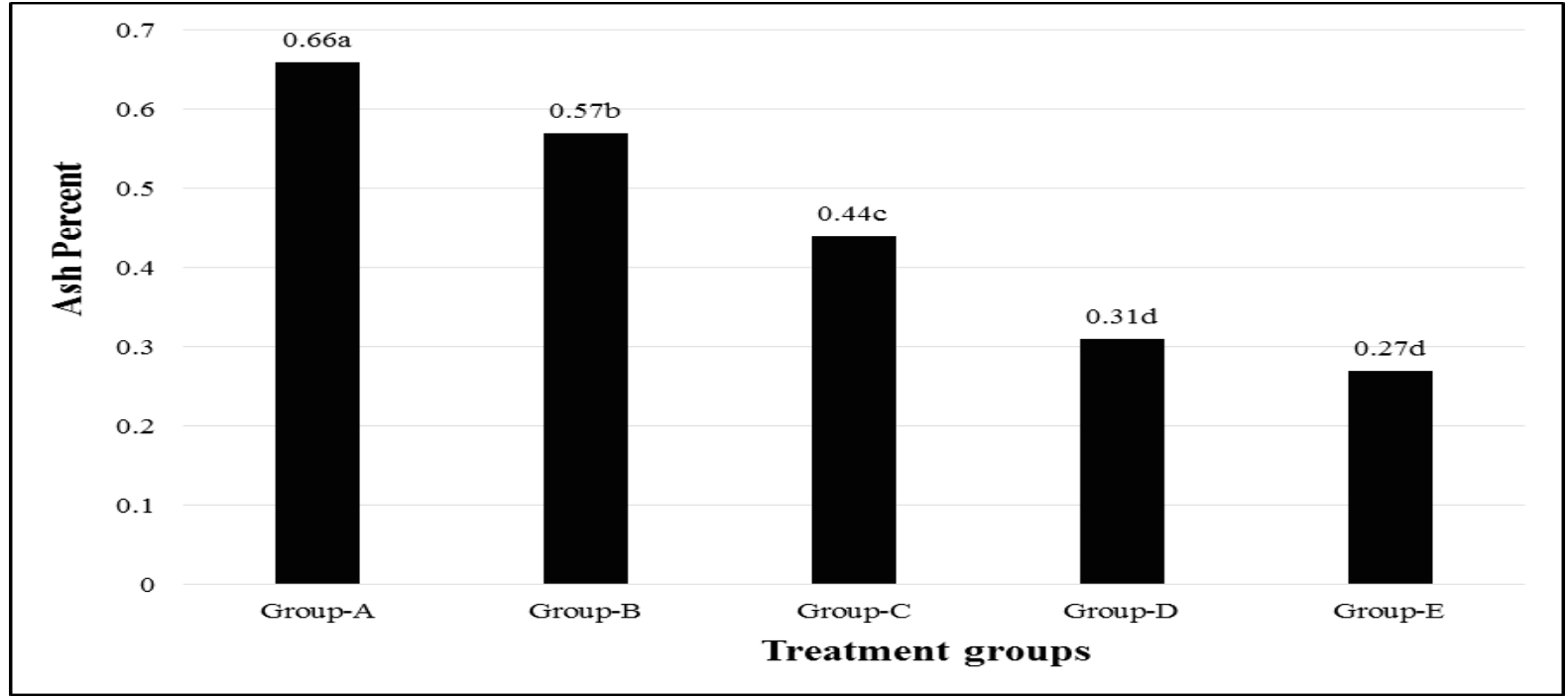

Group-A = Control (ad-libitum feed + water $)$

Group-B $=2$ times feed (Morning 6:00 AM and 6:00 PM) + ad-libitum water

Group-C $=3$ times feed (6:00 AM, 2:00 Noon and 10:00 PM) + ad-libitum water

Group-D $=$ Ad-libitum feed for 24 hours +2 times water (6:00 AM and 6:00 PM)

Group-E $=$ Ad-libitum feed for 24 hours +3 time water (6:00 AM, 2:00 PM and 10 PM)

Figure 6. Effect of different water and feeding frequencies on milk ash percent of Holstein friesian cows 


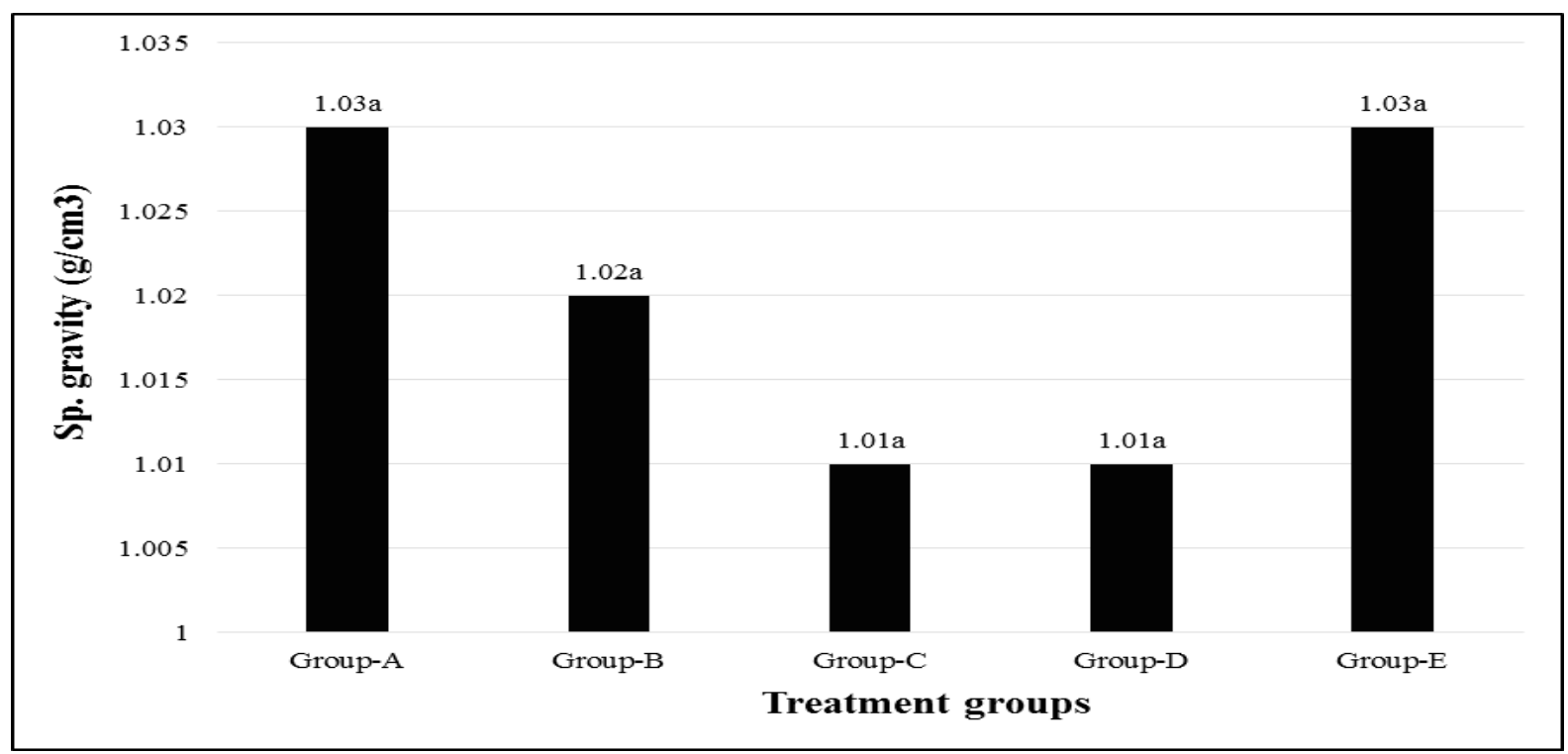

Group-A = Control (ad-libitum feed + water)

Group-B $=2$ times feed (Morning 6:00 AM and 6:00 PM) + ad-libitum water

Group-C $=3$ times feed (6:00 AM, 2:00 Noon and 10:00 PM) + ad-libitum water

Group-D = Ad-libitum feed for 24 hours +2 times water (6:00 AM and 6:00 PM)

Group-E $=$ Ad-libitum feed for 24 hours +3 time water (6:00 AM, 2:00 PM and 10 PM)

Figure 7. Effect of different water and feeding frequencies on milk specific gravity of Holstein friesian cows

\section{Conclusion}

Study concludes that the milk composition of Holstein friesian cows is considerably impaired by different dietary regimes. Protein found prominently improved in group B, lactose and ash content were better in group A, fat was higher in group $\mathrm{D}$, while solid not fat and total solids were better in group E, D respectively.

\section{Authors' contributions}

Conceived and designed the experiments: QA Memon, MH Baloch \& AA Khaskheli, Performed the experiments: QA Memon, Analyzed the data: MN Rajput, Contributed reagents/ materials/ analysis tools: MG Shah, TA Korejo \& MA Solangi, Wrote the paper: AA Khaskheli.

\section{References}

1. Alamer M (2015). Effect of water restriction on lactation performance of Aardi goats under heat stress conditions. Small Ruminant Res 84: 76-81.

2. Burgos MS, Senn M, Sutter F, Kreuzer M \& Langhans W (2015). Effect of water restriction on feeding and metabolism in dairy cows. Amari J Physiol 28 (1): 418-427.

3. Devendra C (2014). The comparative efficiency of feed utilization of ruminants in the tropics. Trop Sci 13: 123-132.

4. Meyer J, Benlamlih S \& Dahlborn K (2014). Effect of dehydration, rehydration and hyperhydration in the black Moroccan goat. Com Biochem Phys A 109: 1017-1026.

5. Little W, Sansom BF, Manston R \& Allen WM (2012). Effects of restricting the water intake of dairy cows upon their milk yield, body weight and blood composition. J Anim Prod 22: 329-339.

6. Aganga U, Dahlborn K \& Olsson K (2012). Effects of intermittent watering on water balance and feed intake in male Ethiopian Somali goats. Small Ruminant Res 67: 45-54.

7. Banerjee GC (2009). A textbook of animal husbandry. 8th Edi. Oxford and IBH publishing Co. Pvt. Ltd. New Dehli. 
8. Andre T, Alamer M \& Al-Hozab A (2014). Effect of water deprivation and season on feed intake, body weight and thermoregulation in Awassi and Najdi sheep breeds in Saudi Arabia. J Arid Environ 59: 7184.

9. Senn M, Gross-Luem SINA, Kaufmann A \& Langhans W (2016). Effect of water deprivation on eating patterns of lactating cows fed grass and corn pellets ad libitum. Physiol Behav 60: 1413-1418.

10. Salama AAK, Such X, Caja G, Rovai M, Casals R, Albanell E, Marn MP \& Mart A (2013). Effects of once versus $2 \mathrm{x}$ daily milking throughout lactation on milk yield and milk composition in dairy goats. J Dairy Sci 86: 16731680.

11. Hilali NE, Maltz A, Halevi \& Shinder D (2015). Metabolism of water, sodium, potassium and chlorine by high yielding dairy cows at the onset of lactation. J Dairy Sci 80: 949-956.

12. Senn MR, Patil VC \& Udar SA (2015). Effect of drinking water frequency on milk yield, fat, total solids and solids-not-fat content in crossbred cows. Indian J Anim Res 38: 47-49.

13. Alam M, Das BC, Hassan MM, Ahaduzzaman M, Al Faruk MS \& Hasanuzzaman M (2014). Ruminal acidosis-A case compilation study in
SAQ Teaching Veterinary Hospital, Bangladesh. Vet World 7: 2434-2443.

14. Peel CJ, Fronk TJ, Bauman DE \& Gorewit RC (2013). Effect of exogenous growth hormone in early and late lactation on lactational performance of dairy cows. J Dairy Sci 66: 776-782.

15. Stockdale E, Stelwagen K, \& Knight $\mathrm{CH}$ (2011). Effect of unilateral once or $2 \mathrm{x}$ daily milking of cows on milk yield and udder characteristics in early and late lactation. J Dairy Res 64: 487-494.

16. Tyrrell HF, Brown ACG, Reynolds PJ, Haaland GI, Peel CJ, Bauman DE \& Steinhour WD (2008). Administration of bovine growth hormone to high yielding Holstein cows. I. Influence on in vivo energy metabolism. J Dairy Sci 65 (1): 120125.

17. VanBaale MJ, Ledwith DR, Thomson $\mathrm{JM}, \quad$ Burgos R, Collier RJ \& Baumgard LH (2015). Effect of increased milking frequency in early lactation with or without recombinant bovine somatotropin. J Dairy Sci 88: 3905-3912.

18. DePeters EJ, Smith NE \& Acedo-Rico J (2015). Three or two times daily milking of older cows and first lactation cows for entire lactation. $J$ Dairy Sci 68: 123-132. 